Original Paper

\title{
The Utilization of Triacontyl-Bonded Silica Coated with Imidazolium Ions for Capillary Ion Chromatographic Determination of Inorganic Anions
}

\author{
Anang SEDYOHUTOMO*, Hiroshi SUZUKI, Chuzo FUJIMOTO \\ Department of Chemistry, Hamamatsu University School of Medicine, 1-20-1 Handayama, Higashi-ku,
}

Hamamatsu 431-3192, Japan

\begin{abstract}
This paper describes the separation and detection of five inorganic anions $\left(\mathrm{I}^{-}, \mathrm{BrO}_{3}^{-}, \mathrm{NO}_{2}^{-}, \mathrm{Br}^{-}\right.$, and $\left.\mathrm{NO}_{3}^{-}\right)$by capillary ion chromatography using 1-alkyl-3-methylimidazolium-coated columns and UV detection at $210 \mathrm{~nm}$. The salts of imidazolium (IM) ions (C2-, C4-, C6-, C8-, C10-, and C18-IMs) are a family of ionic liquids and were newly examined as permanent coating reagents on a triacontyl (C30) -bonded silica reversed phase column. When $40 \mathrm{mM} \mathrm{NaCl}$ aqueous solution was used as an eluent, the elution time of these anions was increased with the length of alkyl chain between C2- and C10-IMs, but turned to decrease with C18-IM. Good and faster separations were attained using a C18-IM-coated column with $150 \mathrm{mM}$ $\mathrm{NaCl}$ in $25 \%(\mathrm{v} / \mathrm{v})$ acetonitrile- $75 \%(\mathrm{v} / \mathrm{v})$ water. The method was successfully applied to the determination of nitrite, bromide, and nitrate in seawater and river water.
\end{abstract}

Keywords: Ion chromatography; Quaternary ammonium; Water analysis; Ionic liquid; Inorganic anions

\section{Introduction}

Since its advent in 1975, ion chromatography using a separation column of low ion exchange capacity in conjunction with a suppressor column to remove the background conductance of the eluent has been the dominant method for the determination of inorganic anions. To eliminate the suppressor column, anion exchange resins with a sufficiently lower exchange capacity $(c a$. 0.005-0.10 $\mathrm{meq} / \mathrm{g}$ ) have been developed and used with a very dilute eluent [1].

Apart from such fixed-site ion-exchange materials, anion exchange stationary phases can be prepared by permanently coating a variety of stationary phases with quaternary ammonium salts. The majority of permanent coating was performed on octadecyl silica-based reversed-phase materials (particles [2-23] and monoliths [24-28]). Jiang et al. utilized conventional silica columns to modify the particle surface with cetyltrimethylammonium ions [29]. In addition, polystyrene-divinylbenzene polymers $[2-6,30,31]$ and graphitized carbon [23,32-35] were utilized. The quaternary ammonium salts included the salts of different tetraalkylammonium

[9-18,21,24-27,29,30,32-34], $n$-cetylpyridinium $[2-5,8,18,19,27,30,34]$, cationic dyes [6,7], and polyethylenimine [36]. A nonionic polymer surfactant was infrequently used for permanent coating of reversed-phase materials [37].

The advantages of using such permanently coated columns are the ability to vary the ion exchange capacity and the attainment of high column efficiency [29]. In addition, ion chromatography of anions can be practiced in laboratories where only conventional HPLC systems are available.

In this study, triacontyl (C30) silica reversed-phases were permanently coated with 1-alkyl-3-methylimidazolium ion and examined as a stationary phase for ion chromatography of inorganic anions. The salts of imidazolium (IM) ion are a member of the family of materials known as ionic liquids, which have recently gained wide popularity in almost all fields of chemistry, including synthesis, catalysis and electrochemistry. In the field of separation, ion liquids have been used as stationary phases for GC and HPLC, eluent additives for HPLC and CE, and capillary-wall coating

Received: 23 March 2021

Accepted: 29 July 2021

J-STAGE Advance Published: 24 August 2021

DOI: $10.15583 /$ jpchrom.2021.009
Tel: +81-53-435-2320; Fax: +53-435-2320

E-mail: anang@hama-med.ac.jp 
materials for CE (see a review [38] regarding this issue). An IM salt was covalently immobilized on silica particles and used for separation of inorganic and organic anions [39-42]. IM ionic liquids were also used as the mobile phase additives in reversed phase liquid chromatography for analysis of anions [43-45]. In the present study, the preparation of IM-based stationary phases was accomplished by a permanent coating procedure; its simplicity is a distinct advantage over the synthetic methods.

\section{Experimental}

\subsection{Reagents}

Acetonitrile was of HPLC grade from Merck (Darmstadt, Germany). Sodium chloride, used as an eluent additive, and chemicals used in the preparation of standard sample solutions were of analytical reagent grade and were purchased from FUJIFILM Wako Pure Chemical Corporation (Osaka, Japan) and Kanto Chemical (Tokyo, Japan). All eluents and standard mixture solutions were prepared using deionized water which was produced by a Model WG-23 water purification system (Yamato Scientific, Tokyo, Japan), and prior to use, filtrated with a $0.45-\mu \mathrm{m}$ membrane filter. Stock solutions of anions were prepared at a concentration of $100 \mathrm{mM}$ and diluted or mixed for calibration purposes. All standard solutions were stored in polyethylene containers to maintain the concentration.

Tetrafluoroborate salts of 1-ethyl-3-methylimidazolium (C2-IM), 1-butyl-3-methylimidazolium (C4-IM), and 1-methyl-3-octylimidazoulium (C8-IM) were obtained from FUJIFILM Wako Pure Chemical Corporation. 1-Hexyl-3-methyl imidazolium tetrafluoroborate (C6-IM) was obtained from Tokyo Chemical Industry (Tokyo, Japan). 1-Decyl-3-methyl imidazolium tetrafluoroborate (C10-IM) was purchased from Sigma-Aldrich Japan (Tokyo, Japan). 1-Methyl-3-octa decylimidazolium (C18-IM) hexafluorophosphate was obtained from IoLiTec (Denzlingen, Germany). These imidazolium salts were used for preparation of the coating solutions as received.

\subsection{Apparatus}

Eluents were delivered at $4.0 \mu \mathrm{L} / \mathrm{min}$ by a Model 8301 micro-feeder (L. TEX Co., Tokyo, Japan) equipped with a 0.5 -mL gas-tight syringe. Sample injections were made by a Model M435 micro-injection valve (internal dead volume, $50 \mathrm{~nL}$; Upchurch Scientific, Oak Harbor, WA, USA) equipped with a fused silica capillary loop of $50-\mu \mathrm{m}$ i.d. and $76 \mathrm{~mm}$ length, providing the sample loading of $0.20 \mu \mathrm{L}$. Detection was performed at $210 \mathrm{~nm}$ with a Model $870 \mathrm{UV}$ detector (Jasco, Tokyo, Japan) equipped with a flow cell made of a $100-\mu \mathrm{m}$ i.d. fused silica capillary. The detection window was located at $50 \mathrm{~mm}$ from the inlet end of the flow cell capillary which was directly connected to a separation column. The data were acquired by using a Chromato Monitor (Nippon Filcon, Tokyo, Japan). A Model VSR-50R ultrasonic bath (As One, Osaka, Japan) and a Model FB-4000 centrifuge (Kurabo, Osaka, Japan) were used for the preparation of real samples.

\subsection{Column preparation and coating procedure}

Columns were made of a piece of fused silica tubing of $0.32 \mathrm{~mm}$ i.d., $0.45 \mathrm{~mm}$ o.d., and $10 \mathrm{~cm}$ length, obtained from GL Sciences (Tokyo, Japan). The columns were slurry-packed with Develosil C-30-UG-5 (5- $\mu \mathrm{m}$ particle diameter, monomeric C30-silica) obtained from Nomura Chemical (Seto, Japan). The stationary phase was coated by passing a $10 \mathrm{mM}$ solution of an IM salt at a flow rate of 4.0 $\mu \mathrm{L} / \mathrm{min}$ for $50 \mathrm{~min}$; the coating solution was prepared in pure water except for the C18-IM solution which was prepared from $50 \%(\mathrm{v} / \mathrm{v})$ acetonitrile in water. The columns were then conditioned by passing an appropriate solution.

\subsection{Estimation of the amount of the immobilized C18-IM on the column}

The amount of the C18-IM immobilized on a triacontyl-bonded silica reversed phase column was roughly estimated in the following manner. The coated column was flushed with air and then pure acetonitrile was pumped through the coated column at $2.0 \mu \mathrm{L} / \mathrm{min}$ until acetonitrile reached the outlet end of the column. After the column was equilibrated as such for $30 \mathrm{~min}$, the coated column was flushed with acetonitrile at $16 \mu \mathrm{L} / \mathrm{min}$ for $33 \mathrm{~min}$ : the complete release of the C18-IM immobilized on the triacontyl-bonded silica from the column was confirmed by the descending absorption followed by the level-off of absorption at $210 \mathrm{~nm}$. The column effluent $(530 \mu \mathrm{L}$ volume in total) was collected in a $0.6 \mathrm{~mL}$ microcentrifuge tube. Then the column was demounted from the chromatographic system and the micro-injection valve was connected directly to the flow cell of the UV detector, followed by directing a $0.20 \mu \mathrm{L}$ portion of the collected solution with a flow of acetonitrile at $4.0 \mu \mathrm{L} / \mathrm{min}$ to the detector cell where absorbance was monitored at $210 \mathrm{~nm}$. In order to determine the concentration of the C18-IM in the collected solution, a calibration curve (plots of peak area versus C18-IM concentration) was established using a set of C18-IM solutions of known concentration with the same experimental set-up. As a result, the concentration of C18-IM was estimated to be $1.30 \mu \mathrm{g} / \mu \mathrm{L}$. Subsequently, the packing material was pushed out of the column and dried well before it was weighed; the weight of the packing was $5.82 \mathrm{mg}$. Finally, it was calculated that the capacity of the coated column would be $0.35 \mathrm{meq} / \mathrm{g}$.

\subsection{Preparation of real samples}

Surface seawater was collected on the coast of 
Hamamatsu facing the Pacific Ocean and subjected to the ion chromatography analysis after filtration through a $0.45-\mu \mathrm{m}$ membrane filter. River water was collected from the Magome River that flows through the city of Hamamatsu. The river water was centrifuged at 12000-rpm for $15 \mathrm{~min}$ and then filtrated with a $0.45-\mu \mathrm{m}$ membrane filter.

\section{Results and discussion}

\subsection{Coating of C30-silica with IMs}

It is not the first time to use C30-silica for permanent coating of quaternary ammonium ion: Rong et al. used hexadimethrine bromide (cationic polymer) coated on C30 silica particles for determination of iodine in seawater [46]. In this study, ten $\mathrm{mM}$ solutions of 1-alkyl-3-methyl imidazoliums possessing various alkyl chain lengths (C2-, C4-, C6-, C8-, and C10-IMs) were prepared in pure water, while that of C18-IM was prepared in a $50: 50(\mathrm{v} / \mathrm{v})$ water-acetonitrile mixture. The coating solutions were pumped through a $\mathrm{C} 30$-silica packed column at $4.0 \mu \mathrm{L} / \mathrm{min}$ for a period of $50 \mathrm{~min}$, with the column effluent directed through the UV detector set at $210 \mathrm{~nm}$. The column was then flushed with $40 \mathrm{mM} \mathrm{NaCl}$ in water until the baseline was stabilized. Sample injection was made at this point. The columns coated with $\mathrm{C} 2-, \mathrm{C} 4-$, and C6-IMs provided stable baseline within $20 \mathrm{~min}$, while the $\mathrm{C} 8$ - and C10-IM-coated columns took approximately 1.5 and $2.0 \mathrm{~h}$, respectively, before the baseline was stabilized. The C18-IM-coated column gave a stable baseline within $10 \mathrm{~min}$. Such differences in time required for equilibration may be due to the differences in the amounts of individual IMs accumulated on the bonded-phase and due to the difference of solubilities of individual IMs in the $\mathrm{NaCl}$ aqueous solution.

The first chromatographic evaluation was performed using a test mixture of inorganic anions composed of iodate, bromate, nitrite, bromide and nitrate. As can be seen in Fig.1, these anions are more strongly retained on the column as the alkyl chain becomes longer from ethyl to decyl in the IM, but the elution times of the anions decreased on the octadecyl-IM column as compared with that on the decyl-IM column. The complete separation of individual anions was accomplished on the C10-IM-coated column, whereas bromate and nitrite coeluted on the C18-IM-coated column. What was worse, we found that retention of each anion changed with the running time. On the C10-IM-coated column the elution time of every anion initially increased and after a certain point of time, turned to decline (Fig. 2(A)). The decrease in the retention of anions on the C10-IM coated column may signify that the IM was released from the reversed-phase material in the column. On the other hand, the retention of anions continued to increase on the C18-IM coated column (Fig. 2(B)).

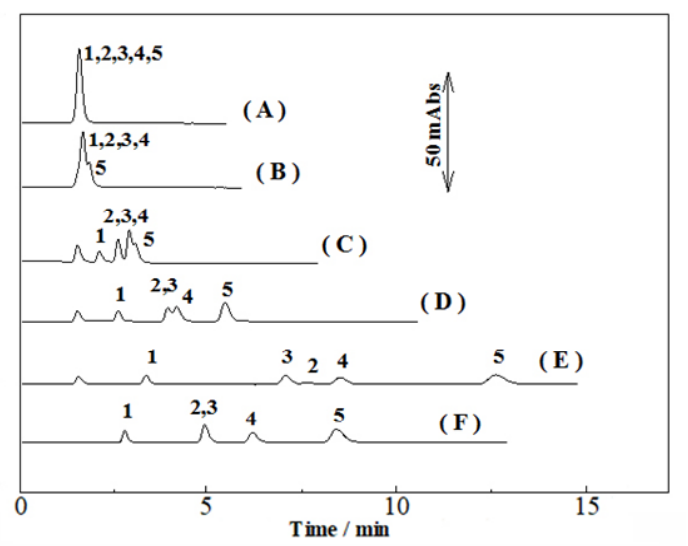

Fig. 1. Separations of inorganic anions on the $\mathrm{C} 30$-silica columns coated with imidazoliums (IMs) possessing different alkyl chain lengths. (A) C2-IM, (B) C4-IM, (C) C6-IM, (D) C8-IM, (E) C10-IM, (F) C18-IM. Peaks: 1, iodate; 2 , bromate; 3 , nitrite; 4 , bromide; 5 , nitrate.

Eluent: $40 \mathrm{mM} \mathrm{NaCl}$ aqueous solution at $4.0 \mu \mathrm{L} \mathrm{min}{ }^{-1}$. Sample injection volume: $0.20 \mu \mathrm{L}$. Detection: UV at 210 $\mathrm{nm}$. Analyte concentration: $0.5 \mathrm{mM}$.
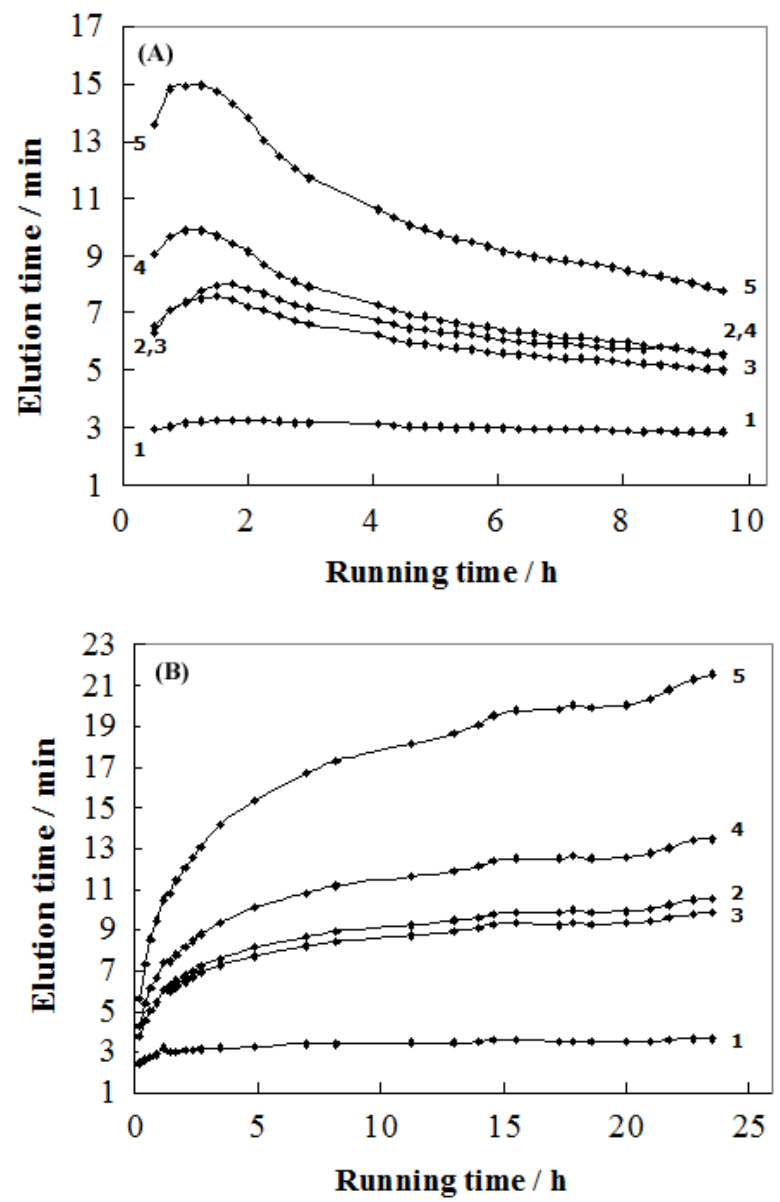

Fig. 2. Variation of the elution times of anions on (A) C10-IM and (B) C18-IM coated reversed-phase columns with running time. Analytes: (1) iodate; (2) bromate; (3) nitrite; (4) bromide; (5) nitrate. Chromatographic conditions as in Fig.1. 
According to the paper by $\mathrm{Li}$ et al. [47], it follows that water promotes the ionic dissociation of IMs significantly compared with acetonitrile because of the high dielectric constant and proton-donating ability of water. It seems therefore that as acetonitrile surrounding the IM sorbed on the reversed-phase material was replaced with water, the effective charge on the IM available to interact with the analytes increased, thereby increasing the retention.

\subsection{Effect of addition of acetonitrile into the eluent}

Acetonitrile was added into the eluent containing $40 \mathrm{mM}$ $\mathrm{NaCl}$ in an attempt to keep the analyte retention under control. Anion separations were performed using an eluent containing $40 \mathrm{mM} \mathrm{NaCl}$ in $25 \%(\mathrm{v} / \mathrm{v})$ acetonitrile-75\%(v/v) water on the C18-IM-coated column (Fig. 3(B)), where individual anions eluted earlier compared to when $40 \mathrm{mM}$ $\mathrm{NaCl}$ in water (Fig. 3(A)) was used as the eluent. Interestingly, bromate and nitrite ions were successfully separated with this particular eluent. Although at the present stage it is difficult to clarify the effect of added acetonitrile on the their elution behavior, it is known that various organic solvents can exert a variety of effects on the analyte ions [48].

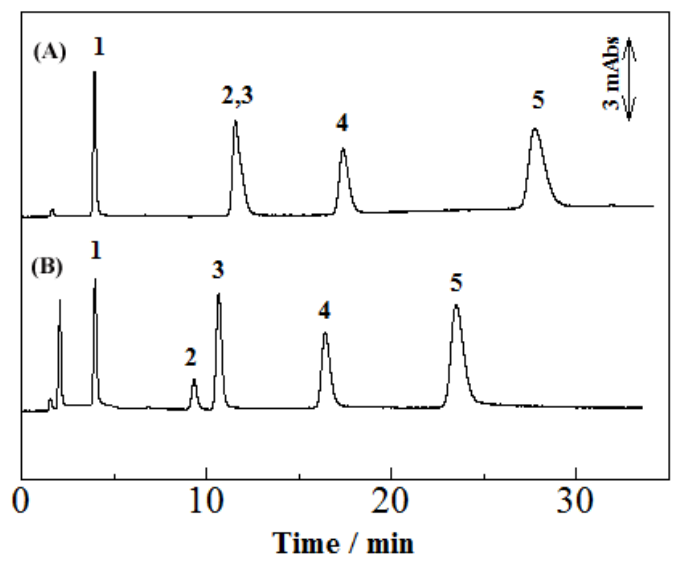

Fig. 3. Effect of acetonitrile in eluent on the separation of anions. The eluent was switched from $40 \mathrm{mM} \mathrm{NaCl}$ in water (A) to $40 \mathrm{mM} \mathrm{NaCl}$ in water with $25 \%(\mathrm{v} / \mathrm{v})$ acetonitrile- $75 \%(\mathrm{v} / \mathrm{v})$ water (B). Separation and detection conditions as in Fig. 1 except the fact that a $\mathrm{C} 30$-packed column coated with C18-IM was used. Peaks: (1) iodate; (2) bromate; (3) nitrite; (4) bromide; (5) nitrate.

\subsection{Speed up of conditioning}

When the C18-IM-coated column was conditioned with an eluent containing $40 \mathrm{mM} \mathrm{NaCl}$ in $25 \%(\mathrm{v} / \mathrm{v})$ acetonitrile- $75 \%(\mathrm{v} / \mathrm{v})$ water, it took more than $20 \mathrm{~h}$ until each anion gave a constant elution time. In order to speed up the conditioning, $1 \mathrm{M} \mathrm{NaCl}$ aqueous solution was passed through a C18-IM coated column for 15, 30, 45 and $60 \mathrm{~min}$, and immediately after that, $40 \mathrm{mM} \mathrm{NaCl}$ in $25 \%(\mathrm{v} / \mathrm{v})$ acetonitrile-75\%(v/v) water was passed through each column for a short period of time. Fig. 4 shows the change in the elution time of the last peak (nitrate) on the columns which were conditioned over the different periods of time. It is obvious that almost constant elution times of anions are achieved by passing $1 \mathrm{M} \mathrm{NaCl}$ aqueous solution through the column for about one hour.

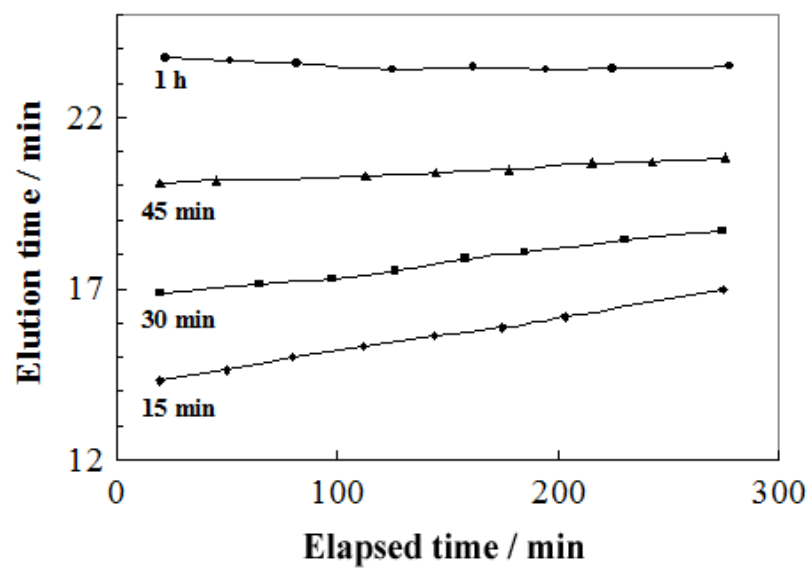

Fig. 4. Effect of time periods for conditioning on the elution time of nitrate. A C18-IM-coated column was conditioned by passing $1 \mathrm{M} \mathrm{NaCl}$ in water at $4.0 \mu \mathrm{L} / \mathrm{min}$ for different periods of time. Eluent: $40 \mathrm{mM} \mathrm{NaCl}$ in $25 \%(\mathrm{v} / \mathrm{v})$ acetonitrile- $75 \%(\mathrm{v} / \mathrm{v})$ water. Flow rate: 4.0 $\mu \mathrm{L} / \mathrm{min}$. Detection: UV at $210 \mathrm{~nm}$.

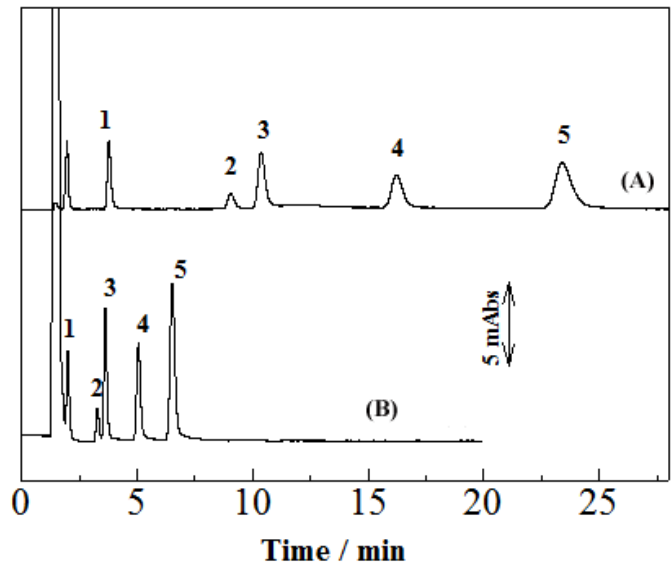

Fig. 5. Separation of inorganic anions on a C18-IM-coated column with $40 \mathrm{mM}$ (A) and $150 \mathrm{mM}$ (B) $\mathrm{NaCl}$ in $25 \%(\mathrm{v} / \mathrm{v})$ acetonitrile- $75 \%(\mathrm{v} / \mathrm{v})$ water. Flow rate: $4.0 \mu \mathrm{L} / \mathrm{min}$. Sample injection volume: $0.20 \mu \mathrm{L}$. Detection: UV at $210 \mathrm{~nm}$. Peaks: (1) iodate; (2) bromate; (3) nitrite; (4) bromide; (5) nitrate.

\subsection{Shortening the time required for separation}

When $40 \mathrm{mM} \mathrm{NaCl}$ in $25 \%(\mathrm{v} / \mathrm{v})$ acetonitrile- $75 \%(\mathrm{v} / \mathrm{v})$ water was used as the eluent, the last peak eluted at 23.5 $\mathrm{min}$. To enable to shortening of time required for analysis, the eluent was substituted for $150 \mathrm{mM} \mathrm{NaCl}$ in $25 \%(\mathrm{v} / \mathrm{v})$ acetonitrile- $75 \%(\mathrm{v} / \mathrm{v})$ water. The resultant chromatogram is shown in Fig. 5, where for comparison that obtained with 
an eluent of $40 \mathrm{mM} \mathrm{NaCl}$ in $25 \%(\mathrm{v} / \mathrm{v})$ acetonitrile- $75 \%$ $(\mathrm{v} / \mathrm{v})$ water is also shown. It is seen that by use of the higher-salinity eluent, the separation can be completed within $7 \mathrm{~min}$. The elution order of five anions is the same as that obtained with silica columns modified with cetyltrimethylammonium ion [29]. The reproducibility of analysis for the inorganic anions is demonstrated in Fig. 6, where ion chromatograms obtained every hour are presented. It appears that the C18-IM is strongly retained on the reversed phase material through hydrophobic interaction.

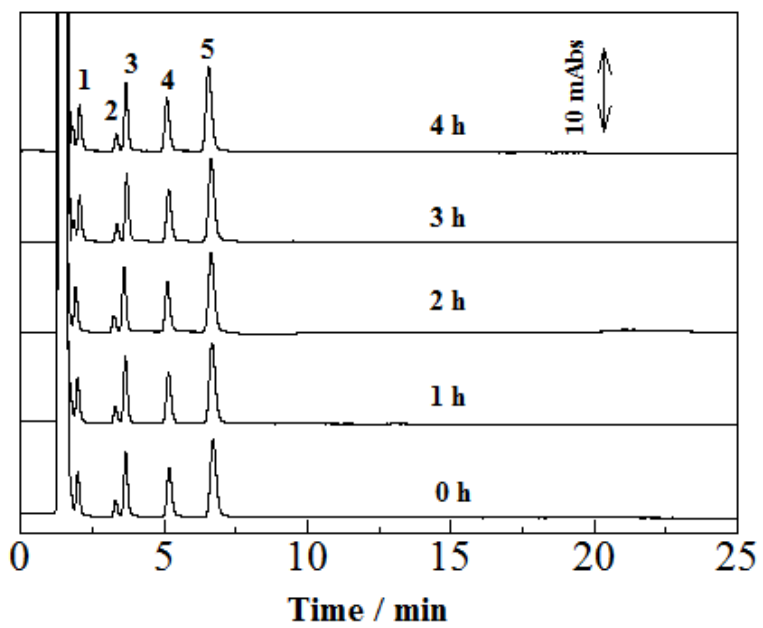

Fig. 6. Long-term stability of a C18-IM-coated column after conditioned with $1 \mathrm{M} \mathrm{NaCl}$ aqueous solution for $1 \mathrm{~h}$. Eluent: $150 \mathrm{mM} \mathrm{NaCl}$ in $25 \%(\mathrm{v} / \mathrm{v})$ acetonitrile- $75 \%(\mathrm{v} / \mathrm{v})$ water at 4.0

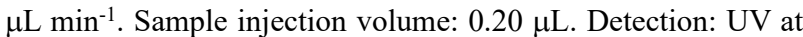
210 nm. Peak identifications as in Fig.5.

\subsection{Effect of salinity in the eluent on the retention factor}

The influence of salinity on the retention of the analytes was investigated using eluents containing $\mathrm{NaCl}$ within the range of $40 \mathrm{mM}$ to $300 \mathrm{mM}$ in $25 \%(\mathrm{v} / \mathrm{v})$ acetonitrile- $75 \%(\mathrm{v} / \mathrm{v})$ water. Increasing the salinity tended to decrease the retention factor $(k)$. As can be seen in Fig.7, there is almost linear relationships between the logarithm of the retention factor $(\log k)$ and the logarithm of the $\mathrm{NaCl}$ concentration in the eluent. The slopes for the analytes were $-0.92,-1.08,-1.05,-1.04$ and -1.06 for iodate, bromate, nitrite, bromide, and nitrate, respectively. Theoretically, the value of slope is determined by the ratio of the valence of analyte ion to the valence of the chloride ion in the eluent. Therefore, the slopes should be equal to -1 : the separation of the analytes is based on ion-exchange mechanism.

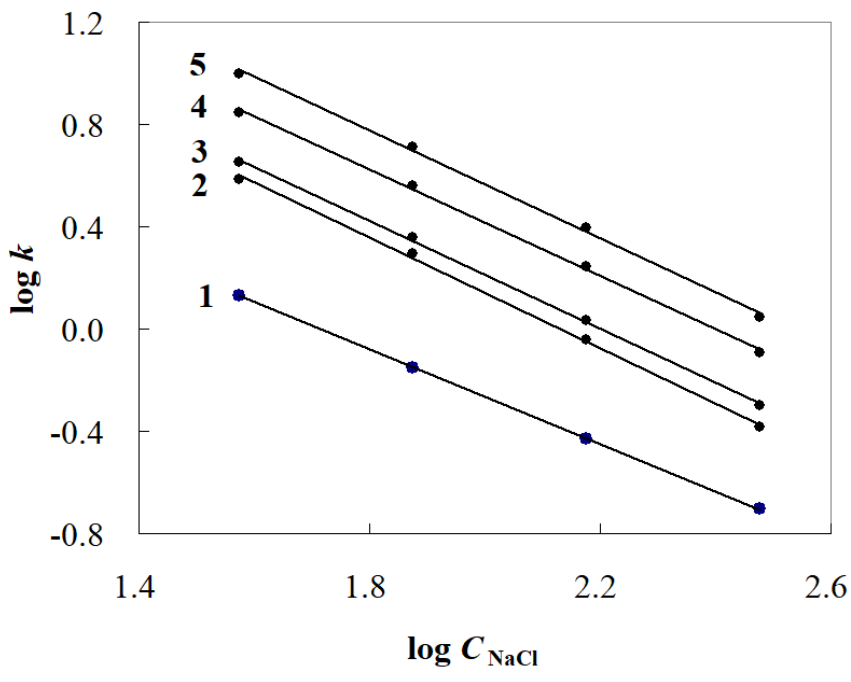

Fig. 7. The logarithm of the retention factor versus the logarithm of $\mathrm{NaCl}$ concentration (mM). Eluent: $40 \mathrm{mM}$ to 300 $\mathrm{mM} \mathrm{NaCl}$ in $25 \%(\mathrm{v} / \mathrm{v})$ acetonitrile-75\%(v/v) water. Separation and detection conditions as in Fig.6. Peak identification as in Fig. 5.

\subsection{Analytical performance}

Reproducibility with respect to retention time, peak area and peak height for different anions present in a single mixture was studied under the established operating conditions, which are summarized in Table 1. The results obtained (Table 2) show a maximum RSD of $1.10 \%$ for the retention time, $4.21 \%$ for the peak area and $3.38 \%$ for the peak height. As compared with conventional silica column modified with cetyltrimethylammonium bromide (CTAB) [29], the RSDs in retention times obtained in the present method are smaller except for iodate ion, while the RSD values in peak area and peak height are almost comparable. Furthermore the analysis time achieved in our method is shorter than that obtained with the CTAB-modified silica column.

The limits of detection (LOD) for the anions detected at $210 \mathrm{~nm}$ ranged from 3 to $5 \mathrm{mM}$ (from 0.14 to $0.82 \mathrm{ppm}$ ), with the exception of bromate that more weakly absorbs at this particular wavelength compared with other anions. The LOD values achieved with the present method are worse than those obtained with the CTAB-modified silica column coupled to a conventional UV detector set at $210 \mathrm{~nm}$ [29]. A good linear relationship between analyte concentration and peak area was obtained over the concentration range studied (from $62.5 \mu \mathrm{M}$ to $1.00 \mathrm{mM}$ ) as revealed by the values of the square of the correlation coefficient $\left(R^{2}\right)$ ranging from 0.997 to 0.999 .

The stability of the IM-coated stationary phase was examined. The retention time $\left(t_{\mathrm{R}}\right)$ remained insignificantly changed over a period three months: the $t_{\mathrm{R}}$ of iodate ranged from 1.88 to $1.98 \mathrm{~min}$. 
Table 1. Operating chromatographic conditions.

\begin{tabular}{ll}
\hline Column & $\begin{array}{l}\text { Develosil C30-UG-5 column }(0.32 \mathrm{~mm} \\
\text { i.d., } 10 \mathrm{~cm} \text { length) coated with } 200 \mu \mathrm{L}\end{array}$ \\
& of $10 \mathrm{mM} \mathrm{C18-IM} \mathrm{in}(50: 50, \mathrm{v} / \mathrm{v})$ \\
& water/ acetonitrile \\
& $1 \mathrm{M} \mathrm{NaCl}$ at $4.0 \mu \mathrm{L} / \mathrm{min}$ for $1 \mathrm{~h}$ \\
Conditioning & Direct absoption at $210 \mathrm{~nm}$ \\
Detection & $25^{\circ} \mathrm{C}$ \\
Column temperature & $150 \mathrm{mM} \mathrm{NaCl}$ in $25 \%(\mathrm{v} / \mathrm{v})$ acetonitrile- \\
Eluent & $75 \%(\mathrm{v} / \mathrm{v})$ water \\
& $4.0 \mu \mathrm{L} / \mathrm{min}$ \\
Flow rate & $0.20 \mu \mathrm{L}$ \\
Sample injection volume
\end{tabular}

Table 2. The RSDs of the retention time $\left(t_{\mathrm{R}}\right)$, peak area and peak height, LOD at $S / N=3$ of anions, and the coefficient of determination $\left(R^{2}\right)$ of the calibration curves.

\begin{tabular}{|c|c|c|c|c|c|c|}
\hline \multirow[b]{2}{*}{ Analyte } & \multicolumn{3}{|c|}{$\mathrm{RSD}, \%(n=30)$} & \multirow[b]{2}{*}{$\begin{array}{l}\mathrm{LOD} \\
\mu \mathrm{M}(\mathrm{ppm})\end{array}$} & \multirow[b]{2}{*}{$R^{2}$} & \multirow[b]{2}{*}{$\begin{array}{c}t_{\mathrm{R}} \\
\min \end{array}$} \\
\hline & $\begin{array}{l}\text { Retention } \\
\text { Time }\end{array}$ & $\begin{array}{l}\text { Peak } \\
\text { area }\end{array}$ & $\begin{array}{l}\text { Peak } \\
\text { height }\end{array}$ & & & \\
\hline Iodate & 1.10 & 3.35 & 1.20 & $5(0.82)$ & 0.9972 & 1.96 \\
\hline Bromate & 1.05 & 4.06 & 3.30 & $12(1.54)$ & 0.9990 & 3.24 \\
\hline Nitrite & 1.00 & 2.76 & 2.50 & $3(0.14)$ & 0.9992 & 3.59 \\
\hline Bromide & 0.90 & 4.21 & 3.38 & $4(0.33)$ & 0.9991 & 5.05 \\
\hline Nitrate & 0.87 & 2.59 & 2.54 & $3(0.16)$ & 0.9987 & 6.56 \\
\hline
\end{tabular}

\subsection{Analysis of real samples}

Seawater and river water samples were collected, filtered through a $0.45-\mu \mathrm{m}$ membrane filter, and without dilution or concentration, injected into the C18-IM-coated column. The resultant chromatograms are shown in Fig. 8. Nitrite and nitrate are detected in both samples without any interference by matrix ions. A large peak of bromide is observed in the seawater sample. In general, column capacity must be considered when real samples are analyzed using such a small column. It may be noticed that the retention times of these anions for the real samples are the same as those for the standard sample (Fig. 8(A)): this illustrates that the column capacity was sufficiently high to cope with the different sample matrix. The estimated capacity of the C18-IM coated column $(0.35 \mathrm{meq} / \mathrm{g})$ is smaller than that of classical ion-exchange resins (3-5 $\mathrm{meq} / \mathrm{g})$, but higher than that of low-capacity ion-exchangers $(0.005-0.10 \mathrm{meq} / \mathrm{g})$ which have been popular in recent years. The analytical results are summarized in Table 3 . Bromide in seawater was quantified at a level of $43.8 \mathrm{mg} / \mathrm{L}$ which falls within the range of the reported values [49]. It is well known that the concentration levels of nitrite and nitrate in environmental water can vary considerably depending on the extent of human-caused or natural eutrophication, and in fact, a wide range of nitrite and nitrate concentration values are indicated in the literatures $[11,13,16,26]$. Therefore, the concentration level of nitrite and nitrate obtained for our water samples appears to be quite probable.
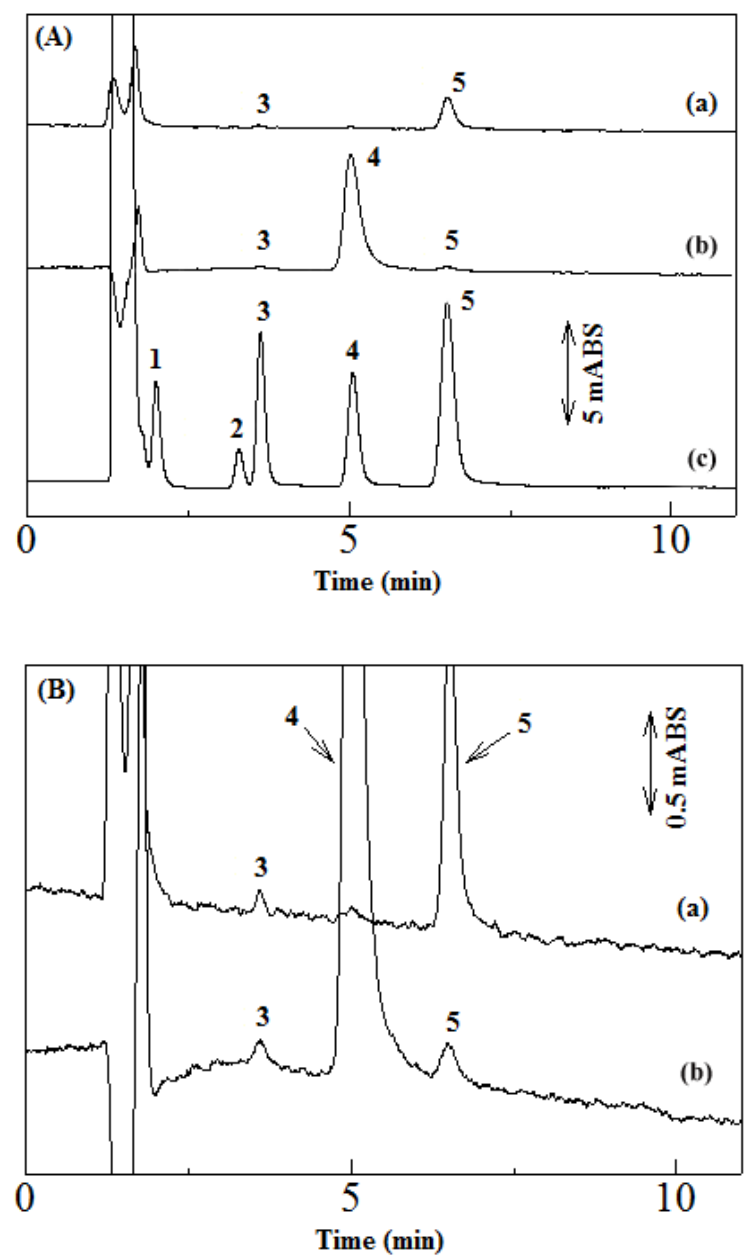

Fig. 8. (A) Ion chromatograms of inorganic anions in river water (a), seawater (b), and standard mixture (c). (B) Enlarged views of (a) and (b). Separation and detection conditions as in Fig.6. Peak identification as in Fig. 5.

Table 3. Analytical results of nitrite, bromide and nitrate in river water and seawater.

\begin{tabular}{lcccc}
\hline \multirow{2}{*}{ Analyte } & \multicolumn{2}{c}{ Seawater } & \multicolumn{2}{l}{ River water } \\
& \multicolumn{2}{c}{$\begin{array}{l}\text { Concentration, RSD, } n=5 \\
\mathrm{M}(\mathrm{mg} / \mathrm{L})\end{array}$} & \multicolumn{2}{c}{ Concentration, RSD, $n=5$} \\
& $\%$ & $\mu \mathrm{M}(\mathrm{mg} / \mathrm{L})$ & $\%$ \\
\hline Nitrite & $5.5(0.25)$ & 3.69 & $5.8(0.27)$ & 2.47 \\
Bromide & $548(43.8)$ & 0.81 & $\mathrm{ND}^{\mathrm{a}}$ & - \\
Nitrate & $7.8(0.48)$ & 2.73 & $82.4(5.1)$ & 1.26 \\
\hline
\end{tabular}

a Not detected. Concentrations were determined based on the peak area. 


\section{Conclusion}

Moderately high-capacity anion-exchange columns were developed by sorption of IM on reversed-phase stationary phases. A C30-silica packed capillary column which was permanently coated with $10 \mathrm{mM} \mathrm{C18}-\mathrm{IM}$ in a $(50: 50, \mathrm{v} / \mathrm{v})$ water-acetonitrile mixture allowed separation and detection of five inorganic anions in $<7 \mathrm{~min}$, using an eluent of 150 $\mathrm{mM} \mathrm{NaCl}$ in $25 \%(\mathrm{v} / \mathrm{v})$ acetonitrile- $75 \%(\mathrm{v} / \mathrm{v})$ water and UV detection at $210 \mathrm{~nm}$. The proposed method seems to be more convenient and effective than other methods [39-42] for preparing columns with moderately high ion exchange capacity.

To illustrate how the present method has real application potential, the method was applied to the determination of nitrite and nitrate in both a local river water and seawater. Bromide was determined in seawater. Due to its moderately high exchange capacity, the IM-coated column can be applied to samples of considerable ionic strength such as seawater.

\section{References}

[1] Gilbert, M. T. High Performance Liquid Chromatography, IOP Publishing, Bristol, 1987, pp. 194-198.

[2] Cassidy, R. M.; Elchuk S. J. Chromatogr. Sci. 1983, 21, 454-459.

[3] Cassidy, R. M.: Elchuk, S. Anal. Chem. 1982, 54, 1558-1563.

[4] Duval, D. L.; Fritz, J. S. J. Chromatogr. A 1984, 295, 89-101.

[5] Barkley, D. J.; Dahms, T. E.; Villeneuve, K. N. J. Chromatogr. A, 1987, 395, 631-640.

[6] Golombek, R.; Schwedt, G. J. Chromatogr. 1988, 452, 283-294.

[7] Müller, G.; Meisch, H.-U. J. Chromatogr. A 1989, 483, 145-151.

[8] Jun, X.; Lima, J. L. F. C.; Montenegro, M. C. B. S. M. Anal. Chim. Acta 1996, 321, 263-271.

[9] Yokoyama, Y.; Suemitsu, H.; Sato, H. Anal. Sci. 2000, 16, 1225-1227.

[10] Hatsis, P.; Lucy, C. A. Analyst 2002, 127, 451-454.

[11] Ito, K.; Ariyoshi, Y.; Tanabiki, F.; Sunahara, H. Anal. Chem. 1991, 63, 273-276.

[12] Ito, K.; Shoto, E.; Sunahara, H. J. Chromatogr. A 1991, 549, 265-272.

[13] Ito, K. J. Chromatogr. A 1997, 764, 346-349.

[14] Ito, K.; Hirokawa, T. Anal. Sci. 2001, 17, 579-581.

[15] Connolly, D.; Paull, B. J. Chromatogr. A 2001, 917, 353-359.

[16] Connolly, D.; Paull, B. Anal. Chim. Acta 2001, 441, 53-62.

[17] Connolly, D.; Paull, B. J. Chromatogr. A 2002, 953, 299-303.
[18] Michigami, Y.; Yamamoto, Y. J. Chromatogr. A 1992, 623, 148-152.

[19] Michigami, Y.; Yamamoto, Y.; Ueda, K. Analyst 1989, 114, 1201-1205.

[20] Yan, Z.; Haddad, P. R.; Fritz, J. S. J. Chromatogr. A 2003, 985, 359-365.

[21] Ohta, K.; Tanaka, K. Bunseki Kagaku, 1995, 44, 713-717.

[22] Hu, W.; Hasebe, K.; Tanaka, K.; Haddad, P. R. J. Chromatogr. A 1999, 850, 161-166.

[23] Helaleh, M. I. H.; Al-Omair, A.; Tanaka, K.; Mori, M. Acta Chromatographica, 2005, 15, 247-257.

[24] Hatsis, P.; Lucy, C. A. Anal. Chem. 2003, 75, 995-1001.

[25] Connolly, D.; Victory, D.; Paull, B. J. Sep. Sci. 2004, 27, 912-920.

[26] Ito, K.; Takayama, Y.; Makabe, N.; Mitsui, R.; Hirokawa, T. J. Chromatogr. A 2005, 1083, 63-67.

[27] Suzuki, A.; Lim, L. W., Hiroi, T.; Takeuchi, T. Talanta 2006, 70, 190-193.

[28] Li, J.; Zhu, Y.; Guo, Y. J. Chromatogr. A 2006, 1118, 46-50.

[29] Jiang, X.-L.; Lim, L. W.; Takeuchi T. Anal. Bioanal. Chem. 2009, 393, 387-391.

[30] Jun, X.; Lima, J. L. F. C.; Montenegro, M. C. B. S. M. Anal. Chim. Acta, 1997, 339, 231-239.

[31] Barkley, D. J.; Charbonneau, J. R.; Chenier, M. J.; Glasgow, C. C.; Graham, J. A. J. Chromatogr. A 1993, 642, 371-377.

[32] Okamoto, T.; Isozaki, A.; Nagashima, H. J. Chromatogr. A 1998, 800, 239-245.

[33] Nagashima, H.; Okamoto, T. J. Chromatogr. A 1999, $855,261-266$.

[34] Yoshikawa, K.; Okamura, M.; Inokuchi, M.; Sakuragawa, A. Talanta 2007, 72, 305-309.

[35] Chambers, S. D.; Lucy, C. A. J. Chromatogr. A 2007, 1176, 178-184.

[36] Sedyohutomo, A.; Suzuki, H.; Fujimoto, C. Anal. Sci. 2012, 28, 625-629.

[37] Rong, L.; Takeuchi, T. J. Chromatogr. A 2004, 1042, 131-135.

[38] Sun, P.; Armstrong, D. W. Anal. Chim. Acta 2010, 661, 1-16.

[39] Qiu, H.; Jiang, S.; Liu, X. J. Chromatogr. A 2006, 1103, 265-270.

[40] Qiu, H.; Jiang, S.; Liu, X.; Zhao, L. J. Chromatogr. A 2006, 1116, 46-50.

[41] Qiu, H.; Mallik, A. K.; Takafuji, M.; Liu, X.; Jiang, S.; Ihara, H. Anal. Chim. Acta, 2012, 738, 95-101.

[42] Sun, Y.; Cabovska, B.; Evans, C. E.; Ridgway, T. H.; Stalcup, A. M. Anal. Bioanal. Chem. 2005, 382, 728-734.

[43] Zhang, Y.; Yu, H. Chromatographia 2017, 80, 
1615-1622.

[44] Zhang, Y.; Yu, H.; Ma, Y.; Cui, G. Anal. Bioanal. Chem. 2018, 410, 7347-7355.

[45] Cui, G.; Yu, H.; Ma, Y. J. Sep. Sci. 2019, 42, 1733-1739.

[46] Rong, L.; Lim, L. W.; Takeuchi, T. Anal. Sci. 2013, 29, 31-34.

[47] Li, W.; Zhang, Z.; Han, B.; Hu, S.; Xie, Y.; Yang, G. J. Phys. Chem. B 2007, 111, 6452-6456.

[48] Haddad, P. R.; Jackson, P. E. Ion Chromatography: Principles and Applications, Elsevier Science B. Amsterdam, 1990, pp. 83-84.

[49] Fukushi, K.; Watanabe, K.; Takeda, S.; Wakida, S. I.; Yamane, M.; Higashi, K.; Hiiro, K. J. Chromatogr. A 1998, 802, 211-217. 